\title{
Pengaruh konsentrasi gula terhadap aktivitas antioksidan pada minuman bir pletok
}

\author{
The effect of sugar concentration with antioxidant level in bir pletok
}

\author{
Dyah Permanasari ${ }^{1}$, Afrinia Eka Sari2 ${ }^{*}$, Mujahidil Aslam ${ }^{3}$
}

\author{
1 Prodi S1 Gizi, STIKes Mitra Keluarga, Jl \\ Pengasinan, Rawa Semut,Bekasi. \\ Indonesia \\ E-mail: dyahpermanasari02@gmail.com \\ 2 Prodi S1 Gizi, STIKes Mitra Keluarga, Jl \\ Pengasinan, Rawa Semut,Bekasi. \\ Indonesia \\ E-mail: afrinia nutri@yahoo.com \\ 3 Prodi S1 Gizi, STIKes Mitra Keluarga, Jl \\ Pengasinan, Rawa Semut,Bekasi. \\ Indonesia. E-mail: \\ mujahidilaslam@stikesmitrakeluarga.ac.id
}

\section{*Korespondensi:}

Prodi S1 Gizi, STIKes Mitra Keluarga, Jl

Pengasinan, Rawa Semut, Bekasi.

Indonesia

E-mail: afrinia nutri@yahoo.com

\section{Riwayat Artikel:}

Diterima tanggal 29 Mei 2020; Direvisi tanggal 30 Agustus 2020; Disetujui tanggal 24 September 2020; Dipublikasi tanggal 25 Mei 2021.

Penerbit:

Politeknik Kesehatan Aceh Kementerian Kesehatan RI

(C) The Author(s). 2021 Open Access

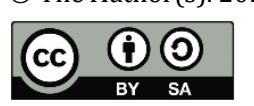
Artikel ini telah dilakukan distribusi berdasarkan atas ketentuan Lisensi Internasional Creative Commons Attribution 4.0

\section{Abstract}

Pletok beer is a spice drink originating from the Betawi tribe. Spices used in pletok brewing include ginger, cloves, lemongrass, cinnamon, secang. This research aims to formulate Bir Pletok which produces high antioxidant activity and high acceptance from panelists. Bir Pletok formulated in the form of a variety sugar concentration, that is $4 \%, 8 \%$, $12 \%$. This research will be examined the antioxidant activity and the sensory analysis of Bir Pletok to find out the panelists' acceptance of its color, smell, and taste. This research will be conducted at STIKes Mitra Keluarga with 30 panelists. This research uses the experimental Descriptive method. The independent variable in this research is the sugar concentration, while the dependent variable is the antioxidant activity. Measurement of the antioxidant activity will use the DPPH test and the hedonic (preference) test using questionnaires. The results showed that the combination treatment of the addition of sugar equal to $4 \%$ is the best results: Antioxidant Capacity $610,278 \mathrm{ppm}$ and a panelist as well as the colors 3,83 (like), odor 3,86 (Like); and sense at 2,86 (Neutral). Overall, the Bir pletok had high antioxidant activity that is the potential to prevent noncommunicable diseases. important factors in the pletok brewing process are heating time and temperature.

Keywords: Antioxidant activity, bir pletok, sugar

\section{Abstrak}

Bir pletok merupakan minuman rempah-rempah yang berasal dari suku Betawi. Bahan rempah yang digunakan pada pembuatan bir pletok antara lain: jahe, cengkeh, sereh, kayu manis, secang. Penelitian bertujuan untuk memformulasikan bir pletok yang menghasilkan tinggi aktivitas antioksidan dan tingkat penerimaan terhadap panelis. Bir pletok diformulasikan dalam bentuk variasi konsentrasi gula pasir yaitu 4\%, 8\%, 12\%. Bir pletok pada penelitian ini diteliti aktivitas antioksidan dan mengetahui penerimaan panelis terhadap warna, aroma dan rasa. Penelitian ini dilakukan di STIKes Mitra Keluarga dengan jumlah panelis 35 orang. Desain Penelitian yang digunakan adalah riset Eksperimental. Variabel bebas pada penelitian ini adalah konsentrasi gula pasir sedangkan variabel terikat adalah aktivitas antioksidan. Pengukuran aktivitas antioksidan menggunakan uji DPPH dan uji hedonik (kesukaan) dengan menggunakan kuesioner. Hasil penelitian ini menunjukkan bahwa kombinasi perlakuan penambahan gula pasir sebesar 4\% merupakan hasil kapasitas antioksidan tertinggi sebesar 610,278 ppm serta kesukaan panelis terhadap warna 3,83 (menyukai), aroma 3,86 (menyukai) dan rasa 2,86 (netral). Secara keseluruhan, minuman bir pletok memiliki aktivitas antioksidan tinggi sehingga berpotensi untuk mencegah penyakit tidak menular.Faktor penting dalam proses pembuatan bir pletok ini adalah waktu dan suhu pemanasan.

Kata Kunci: Aktivitas antioksidan, bir pletok, gula 


\section{Pendahuluan}

Badan Kesehatan Dunia (WHO) menyebutkan bahwa jumlah kematian di dunia yang disebabkan oleh penyakit tidak menular adalah sebesar 71\% (WHO, 2019). Di Indonesia, menurut data Riskesdas 2018 menunjukkan prevalensi penyakit tidak menular mengalami kenaikan jika dibandingkan dengan data Riskesdas 2013 antara lain kanker, stroke, penyakit ginjal kronis, diabetes melitus, dan hipertensi. Prevalensi kanker naik dari 1,4\% menjadi 1,8\% prevalensi strok naik dari $7 \%$ menjadi $10,9 \%$ dan penyakit ginjal kronik naik dari 2\% menjadi 3,8\%. Berdasarkan hasil pemeriksaan gula darah, prevalensi diabetes melitus naik dari 6,9\% menjadi 8,5\%; dan hasil pengukuran tekanan darah, hipertensi naik dari 25,8\% menjadi 34,1\% (Kemenkes RI, 2018).

Kenaikan prevalensi penyakit tidak menular tersebut sangat erat kaitannya dengan pola hidup antara lain merokok. Konsumsi minuman beralkohol, aktivitas fisik, serta konsumsi buah dan sayur (Al Rahmad, 2019). Akibat dari paparan radikal bebas secara terus menerus dan rendahnya asupan vitamin $\mathrm{C}$ dan vitamin $\mathrm{E}$ dapat menyebabkan menipisnya produksi antioksidan alami dalam tubuh sehingga menimbulkan berbagai macam penyakit degeneratif. Aktivitas fisik dengan intensitas rendah dan sedang sangat diperlukan untuk meningkatkan sistem antioksidan karena untuk meminimalkan pengeluaran radikal bebas (Sinaga, 2016).

Antioksidan adalah senyawa yang mampu menangkal atau meredam efek negatif oksidan dalam tubuh, bekerja dengan cara mendonorkan satu elektronnya kepada senyawa yang bersifat oksidan sehingga aktifitas senyawa oksidan tersebut dapat dihambat (Saleh et al., 2012).

Bir pletok merupakan minuman tradisional yang berasal dari betawi yang kaya akan kandungan zat antioksidannya (Ishartani et al., 2012). Bir pletok merupakan minuman yang sehat dan segar yang terbuat dari rempah rempah seperti jahe, serai, cengkeh, kayu manis dan kayu secang yang digunakan untuk sebagai penambah warna merah alami. Minuman bir pletok tidak mengandung alkohol sehingga apabila di konsumsi tidak menimbulkan efek mabuk ataupun pusing. Penelitian mengenai kandungan antioksidan telah dilakukan sebelumnya namun apakah konsentrasi gula dapat berpengaruh pada kandungan antioksidan bir pletok belum pernah dilakukan penelitian sebelumnya (Ishartani et al., 2012).

Pembuatan bir pletok diperlukan komposisi bahan tambahan untuk menghasilkan cita rasa yang khas dari bir pletok itu sendiri, salah satu bahan yang ditambahkan yaitu gula pasir untuk menambahkan rasa manis dan aroma yang dapat memberikan rasa segar pada minuman bir pletok. Efek penambahan bahan ke dalam suatu produk akan memungkinkan adanya perubahan kandungan yang terdapat pada bir pletok, salah satunya proses degradasi antioksidan (Ishartani et al., 2012).

Degradasi antioksidan merupakan kerusakan yang terjadi pada senyawa antioksidan akibat dari berkurangnya kadar antioksidan. Proses degradasi antioksidan dapat terjadi selama proses ekstraksi pengolahan makanan dan penyimpanan, serta faktor lain yang mempengaruhi stabilitasnya seperti pengaruh $\mathrm{pH}$, temperatur, cahaya serta gula (Andarwulan \& Fitri, 2012). Perbedaan persentase aktivitas antioksidan pada setiap perlakuan sirup dipengaruhi oleh jumlah konsentrasi gula pasir yang berbeda-beda (Pujimulyani et al., 2010). Kandungan rempah yang terkandung dalam bir pletok mempunyai kemampuan mencegah terjadinya oksidasi (antioksidan) yang disebabkan oleh berbagai faktor lingkungan seperti: panas, radiasi, sinar ultraviolet, rokok, dan alkohol. Radikal bebas bisa berada di luar tubuh ataupun terbentuk di dalam tubuh. Selain itu, senyawa fenolik yang ada dalam rempah memiliki peran penting dalam menghambat radikal bebas, seperti gingerol dalam jahe dan eugenol dalam cengkeh (Hui et al., 2010). Menurut Kurniasari et al. (2018), jahe mengandung berbagai senyawa antioksidan yaitu zingiberol $28,93 \%$, zingerol $33,23 \%$, dan zingeron $36,75 \%$. Jahe juga mengandung sodium $0,03 \%$, potassium $1,4 \%$, vitamin B1 0,05 mg/100 g, vitamin B2 0,13 $\mathrm{mg} / 100 \mathrm{~g}$, niasin $1,9 \%$ dan vitamin $\mathrm{C} 12$ $\mathrm{mg} / 100 \mathrm{~g}$.

Bir pletok identik dengan pemakaian bahan penyegar secang. Secang mengandung senyawa Flavonoid. Flavonoid merupakan golongan senyawa bahan alam dari senyawa fenolik yang banyak merupakan pigmen tumbuhan (Widowati, 2013). Selain secang bahan rempah lain yang digunakan dan mengandung bahan biokatif adalah 
cengkeh. Senyawa eugenol merupakan komponen utama yang terkandung dalam minyak atsiri cengkeh. Eugenol mengandung senyawa aktif seperti saponin, flavonoid, tannin, dan minyak atsiri (Kurniasari et al., 2018). Berdasarkan kajian latar belakang diatas, maka penulis membuat suatu intervensi minuman local sebagai antioksidan tubuh. Oleh karena itu, penelitian ini dilakukan bertujuan untuk memformulasikan bir pletok yang menghasilkan tinggi aktivitas antioksidan dan tingkat penerimaan terhadap panelis.

\section{Metode}

Penelitian ini merupakan penelitian eksperimental yang dilakukan untuk memprediksi suatu fenomena. Protokol penelitian ini telah mendapat persetujuan dari komisi etik yaitu nomor: 871/KEP/USU/2020. Desain penelitian yaitu menggunakan Rancangan Acak Lengkap (RAL) dengan satu faktor tiga taraf yaitu faktor penambahan gula pasir 4\%: $8 \%: 12 \%$ (b/v) terhadap aktivitas antioksidan dan setiap perlakuan dilakukan 3 kali pengulangan. Variabel bebas pada penelitian ini adalah konsentasi gula pasir, variabel terikat penelitian ini adalah aktivitas antioksidan dan variabel kontrol adalah bir pletok tanpa penambahan gula.

Analisa aktivitas antioksidan dalam peneltian ini menggunakan metode DPPH. Metode DPPH atau (1,1-difenil-2-pikrilhidrazil) merupakan metode uji aktivitas antioksidan yang paling banyak dilakukan (Ikhrar et al., 2019). Metode DPPH dipilih karena memiliki beberapa keunggulan, diantaranya yang mudah dan cepat untuk mengevaluasi antioksidan secara spektrofotometri, selain itu sederhana, sensitif serta membutuhkan sedikit sampel.

Uji DPPH merupakan salah satu metode uji pengukuran aktivitas antioksidan di dalam bahan pangan. Uji DPPH memiliki beberapa kelebihan antara lain uji ini tidak spesifik untuk keterangan komponen antioksidan, tetapi digunakan untuk pengukuran kapasitas antioksidan total pada bahan pangan. Pengukuran total kapasitas antioksidan akan membantu untuk memahami sifat-sifat fungsional bahan pangan.

Aktivitas antioksidan minuman dihitung berdasarkan kesetaraannya dengan aktivitas antioksidan asam askorbat yang dinyatakan dalam ppm AEAC (Ascorbic acid Equivalent Antioxidant Capacity) (Zuidar et al., 2014).
Hasil uji kimia minuman bir pletok dianalisis secara deskriptif dengan menggunakan grafik dan uji T-test sedangkan untuk uji hedonik menggunakan nilai rata-rata dengan metode deskriptif kualitatif berupa kuesioner dilakukan oleh 35 panelis tidak terlatih. Uji hedonic dilakukan pada laboratorium uji organoleptik STIKes Mitra Keluarga. Tingkat kesukaan ini disebut sebagai skala penilaian, dalam penelitian ini skala yang digunakan penulis seperti $1=$ sangat tidak suka, $2=$ tidak suka, $3=$ netral, $4=$ suka dan $5=$ sangat suka. Nilai rata-rata yang diperoleh kemudian di kategorikan, jika $\leq 1,4$ dikeretriakan sangat tidak suka, 1,5-2,4 dikriteriakan tidak suka, 2,5-3,4 dikriteriakan netral, 3,5 -4,4 dikriteriakan suka dan $\geq 4,5$ dikriteriakan sangat suka.

Uji Hedonik dilakukan di STIKes Mitra Keluarga sedangkan untuk analisis DPPH dilakukan di laboratorium Biofarmaka, IPB. Berikut alur untuk pembuatan bir pletok:

1. Jahe bakar gepuk, kayu manis, cengkeh, serai dan secang yang sudah dibersihkan.

2. Ditambahkan air $1 \mathrm{~L}$ dan direbus hingga mendidih

3. Disaring dan ditambahkan gula pasir dengan formulasi berbeda sebanyak $4 \%, 8 \%, 12 \% / 100 \mathrm{~mL}$

4. Bir pletok siap dianalisa

Uji statistik yang digunakan adalah uji ANOVA (Analyze of Variance) untuk melihat apakah ada pengaruh perbedaan penambahan konsentrasi gula yang ditambahkan dengan kandungan antioksidannya.

\section{Hasil dan Pembahasan}

Kapasitas penangkapan radikal bebas diukur berdasarkan kemampuan Minuman Bir Pletok dalam menangkap radikal DPPH (1,1-difenil-2pikrilhidrazil). DPPH adalah suatu radikal yang cukup stabil dengan memberikan warna ungu pada panjang gelombang $517 \mathrm{~nm}$. Ketika radikal DPPH bereaksi dengan suatu senyawa antioksidan yang dapat mendonorkan atom hidrogen, ia akan tereduksi menjadi DPPH-H (Septiana \& Asnani, 2013).

Uji DPPH (1,1-difenil-2-pikrilhidrazil) pada penelitian ini menggunakan kurva standar asam askorbat yang digunakan sebagai pembanding dibuat dengan konsentrasi $0 ; 7,8125 ; 15,625$; 
31,25; 62,5; 125; 250; 500; 1000 ppm. Dengan demikian, satuan pengukuran dinyatakan sebagai nilai AEAC (Ascorbic Acid Equivalent Antioksidant Capacity).

Table 1. Hasil analisis kapasitas antioksidan minuman Bir Pletok dengan vitamin C

\begin{tabular}{lcccc}
\hline \multirow{2}{*}{ Pelakuan } & \multicolumn{2}{c}{$\begin{array}{c}\text { Kapasitas Antioksidan } \\
\text { (ppmAEAC) }\end{array}$} & $\begin{array}{c}\text { Rata-rata } \pm \text { Standar } \\
\text { Deviasi }\end{array}$ & Nilai p \\
\cline { 2 - 3 } & Bir Pletok & Vitamin C & & \\
\hline Bir Pletok (kontrol) & 564,722 & 500 & $592,222 \pm 19,38$ & 0,000 \\
Bir Pletok 1 (gula $4 \% / 100 \mathrm{ml}$ ) & 610,278 & & & \\
Bir Pletok 2 (gula $8 \% / 100 \mathrm{ml})$ & 596,944 & & & \\
Bir Pletok 3 (gula $12 \% / 100 \mathrm{ml})$ & 596,944 & & & \\
\hline
\end{tabular}

Tabel 1. hasil analisis ilustrasi rata-rata aktivitas antioksidan minuman bir pletok sebesar 592,22 AEAC dimana setara dengan 600 ppm vit C yang menunjukkan bahwa semakin tinggi konsentrasi vitamin $\mathrm{C}$ maka persentase penangkapan radikal DPPH semakin besar. Berdasarkan hasil analisis dengan menggunakan statistik menunjukkan Pvalue 0,000 (nilai $\mathrm{p}<0,05$ ) bahwa terdapatnya perbedaan hasil rata-rata bir pletok sebesar 592,222 ppm dalam penggunaan berbagai konsentrasi gula terhadap hasil kapasitas antioksidan pada nilai 500 ppm vitamin C.
Selanjutnya, hasil terhadap tingkat penerimaan dilakukan dengan uji hedonik meliputi warna, aroma dan rasa yang dilakukan oleh 35 orang panelis tidak terlatih. Uji hedonik pada minuman bir pletok bertujuan untuk melihat pengaruh pemberian gula dengan konsentrasi yang berbeda dalam kategori warna, aroma dan rasa dengan tingkat penerimaan panelis. Hasil data yang didapatkan dari nilai rata-rata dengan metode deskriptif kualitatif berupa kuesioner dilakukan oleh 35 panelis tidak terlatih.

Tabel 2. Hasil analisis tingkat penerimaan Bir Pletok

\begin{tabular}{lcccc}
\hline \multirow{2}{*}{ Perlakuan } & \multicolumn{3}{c}{ Kategori } & \multirow{2}{*}{ Rata-Rata } \\
\cline { 2 - 4 } Bir Pletok 1 (gula 4\%/100ml) & Warna & Aroma & Rasa & \\
Bir Pletok 2 (gula $8 \% / 100 \mathrm{ml}$ ) & $3,65 \pm 0,747$ & $3,85 \pm 0,845$ & $2,85 \pm 0,912$ & 3,50 \\
Bir Pletok 3 (gula $12 \% / 100 \mathrm{ml}$ ) & $3,60 \pm 0,847$ & $3,65 \pm 0,802$ & $3,94 \pm 0,968$ & 3,74 \\
\hline
\end{tabular}

Tabel 3, hasil yang diperoleh dengan perlakuan bir pletok 4\% memiliki nilai rata-rata 3,51 (suka) dimana kategori warna sebesar 3,82 (suka), aroma 3,85 (suka) dan rasa 2,85 (netral), perlakuan bir pletok $8 \%$ memiliki nilai rata-rata 3,74 (suka) dimana kategori warna sebesar 3,65 (suka), aroma 3,65 (suka) dan rasa 3,94 (suka), sedangkan untuk perlakuan bir pletok 12\% memiliki nilai rata-rata 3,88 (suka) dimana kategori warna sebesar 3,60 (suka), aroma 3,68 (suka) dan rasa 2,85 (netral). Berdasarkan hasil nilai rata-rata uji hedonik pada minuman bir pletok dapat disimpulkan bahwa adanya pengaruh pemberian gula terhadap kesukaan panelis.

Hasil kapasitas antioksidan terendah terdapat pada minuman bir pletok non gula sebesar 564,722 ppm AEAC dan aktivitas antioksidan tertinggi pada konsentrasi gula $4 \%$. Hasil yang diperoleh berbeda pada penelitian sebelumnya yang menyatakan bahwa semakin banyak gula yang ditambahkan maka tingkat aktifitas antioksidan semakin rendah dikarenakan adanya adanya gugus metilasi dan atom $\mathrm{H}$ semakin berkurang akibat adanya gula maka berkurangnya Atom $\mathrm{H}$ akan menurunkan aktivitas antioksidan sebagai pendonor hidrogen pada radikal bebas (Widowati, 2013). Berbeda dengan hasil penelitian Pelealu (2019) yang memperoleh hasil bahwa reaksi mailard dapat meningkatkan senyawa-senyawa yang berpotensi sebagai antioksidan,terutama pada waktu pemanasan meningkat. Senyawa melainodin kelompok produk reaksi mailard memiliki peran dalam meningkatkan aktivitas antioksidan.

Hasil rata-rata kapasitas antioksidan minuman bir pletok sebesar 592,222 ppm AEAC dimana setara dengan $600 \mathrm{ppm}$ vit C yang menunjukkan bahwa semakin tinggi konsentrasi vitamin C maka persentase penangkapan radikal DPPH semakin besar. Semakin tinggi kadar gula, 
maka semakin rendah nilai absorbansinya (Sheikh et al., 2009). Semakin tinggi kemampuan suatu senyawa antioksidan dalam meredam radikal DPPH ditandai dengan semakin kecilnya nilai absorbansi yang terukur (Rifkowaty \& Wardanu, 2016).

Berdasarkan hasil yang telah didapatkan bahwa nilai yang terendah yaitu pada minuman bir pletok non gula. Hal ini diduga karena hasil reaksi Maillard dari gula reduksi dan protein berupa melanoidin (merupakan pigmen coklat dalam gula sebagai produk dari reaksi maillard yang memiliki kapasitas antioksidan) dari pemanasan gula hanya memberikan pengaruh terhadap penangkapan radikal bebas yang kecil. Hal ini diduga karena gula yang ditambahkan dalam minuman memberikan perlindungan terhadap komponen bioaktif minuman. Tentunya, hasil tersebut sesuai dengan penelitian Ishartani et al. (2012) yang menyatakan bahwa penambahan gula dapat meningkatkan kandungan antioksidan.

\section{Kesimpulan}

Terdapat pengaruh konsentrasi gula yang ditambahkan pada bir pletok dengan kandungan antioksidannya. Terdapat perbedaan nyata minuman bir pletok non gula sebagai kontrol dengan minuman bir pletok pada konsentrasi gula $4 \%, 8 \%$ dan $12 \%(\mathrm{~b} / \mathrm{v})$.

\section{Daftar Rujukan}

Al Rahmad, A. H. (2019). Keterkaitan Asupan Makanan dan Sedentari dengan Kejadian Obesitas Pada Anak Sekolah Dasar di Kota Banda Aceh. Buletin Penelitian Kesehatan, 47(1),

67-76. https://doi.org/10.22435/bpk.v47i1.579

Andarwulan, N., \& Fitri, R. (2012). Pewarna Alami Untuk Pangan. South East Asian Food and Agricultural Science and Technology (SEAFAST) Center.

Hui, Y. H., Chen, F., Nollet, L. M. L., Guiné, R. P. F., Martín-Belloso, O., Mínguez-Mosquera, M. I., Paliyath, G., Pessoa, F. L. P., Le Quéré, J.-L., \& Sidhu, J. S. (2010). Handbook of fruit and vegetable flavors (Vol. 64). Wiley Online Library.

Ikhrar, M. S., Yudistira, A., \& Wewengkang, D. S. (2019). Uji Aktivitas Antioksidan Stylissa sp. dengan Metode DPPH (1, 1-difenil-2pikrilhidrazil). Pharmacon, 8(4), 961-967.

Ishartani, D., Kawiji, K., \& Khasanah, L. U. (2012). Produksi bir pletok kaya antioksidan. Jurnal Teknologi Hasil Pertanian, 5(2), 32-39.

Kemenkes RI. (2018). Hasil utama Riset Kesehatan Dasar (RISKESDAS) tahun 2018. In Badan Penelitian dan Pengembangan Kesehatan, Kemenkes RI.

Kurniasari, F. N., Sukoharsono, K. A., Harti, L. B., \& Cempaka, A. R. (2018). Kandungan protein pada minuman fungsional berbasis jahe (Zingiber offinale) dan kacang-kacangan sebagai antiemetik. AcTion: Aceh Nutrition Journal, 3(1), 16-21. https://doi.org/http://dx.doi.org/10.3086 7/action.v3i1.91

Pelealu, K. (2019). Pengaruh pemanasan terhadap aktivitas antioksidan dalam pembuatan gula aren. Chemistry Progress, 4(2), 60-65.

Pujimulyani, D., Wazyka, A., Anggrahini, S., \& Santoso, U. (2010). The Effect of Adding Sugar and Citric Acid on The Antioxidant Activity and Rehydration Time of White Saffron (Curcuma mangga Val.) Instant Powder. Jurnal Agrisains, 1(2), 28-37.

Rifkowaty, E. E., \& Wardanu, A. P. (2016). Pengaruh Ekstraksi Cara Basah dan Cara Kering Terhadap Aktivitas Antioksidan Ekstrak Cengkodok (Melastoma malabathricum L.). Jurnal Aplikasi Teknologi Pangan, 5(1), 10-15.

Saleh, L. P., Suryanto, E., \& Yudistira, A. (2012). Aktivitas antioksidan dari ekstrak tongkol jagung (Zea mays L.). Pharmacon, 1(2), 2024.

Septiana, A. T., \& Asnani, A. (2013). Antioxidan activity of Sargassum duplicatum seaweed extract. Jurnal Teknologi Pertanian, 14(2), 79-86.

Sheikh, T. Z. B., Yong, C. L., \& Lian, M. S. (2009). In vitro antioxidant activity of the hexane and methanolic extracts of Sargassum baccularia and Cladophora patentiramea. Journal of Applied Sciences, 9(13), 24902493.

Sinaga, F. A. (2016). Stress oksidatif dan status antioksidan pada aktivitas fisik maksimal. Generasi Kampus, 9(2), 176-189.

WHO. (2019). World health statistics 2019: monitoring health for the SDGs, sustainable development goals. In World Health Organization. World Health Organization. 
Widowati, W. (2013). Uji fitokimia dan potensi antioksidan ekstrak etanol kayu secang (Caesalpinia sappan L.). Jurnal Kedokteran Maranatha, 11(1), 23-31.

Zuidar, A. S., Hidayati, S., \& Barus, S. B. (2014).
Penggunaan asam perasetat pada proses delignifikasi pulp acetosolv dari ampas tebu dan bambu betung. Jurnal Teknologi \& Industri Hasil Pertanian, 19(1), 11-27. 